\title{
Effect of Therapeutic Feedback on Non-Face to Face Exercise for Forward Head Posture: Posture, Muscle Strength, Pressure pain Threshold
}

\author{
Yeri Kima ${ }^{\oplus}$, Gayoung Kim ${ }^{\circledR}$, Daye Kima ${ }^{\oplus}$, Hyeri Shina ${ }^{\oplus}$, Seonghoon Oha ${ }^{\oplus}$, \\ Pyeonghwa Yua ${ }^{a}$, Kyusang Jung ${ }^{a}{ }^{\circledR}$, Wonseob Shin ${ }^{a}$ \\ ${ }^{a}$ Department of Physical Therapy, College of Health and Medical Science, Daejeon University, Daejeon, Republic of Korea
}

\begin{abstract}
Objective: This study is to investigate the effect of real-time feedback from the therapist on posture, muscle strength, pain of subjects with forward head posture based on a non-face-to-face complex exercise program.

Design: Two-group pretest-posttest design.

Methods: Thirty healthy men and women in their twenties with forward head posture with a Craniovertebral angle of $52^{\circ}$ or less were targeted, the final selection was made as 15 experimental groups who performed the non-face-to-face intervention program while receiving real-time feedback and 15 control subjects who performed the non-face-to-face intervention program without providing feedback. Six of them were eliminated, and a total of 24 were conducted as subjects. All exercise groups performed an exercise program three times a week, 30 minutes each, for a total of two weeks. Before and after exercise, Craniovertebral angle (CVA), CranioRotation angle (CRA), muscle strength, and tenderness threshold were evaluated.
\end{abstract}

Results: Significant differences were shown in both groups in CVA, and tenderness threshold before and after exercise $(p<0.05)$, and CRA, the left middle trapezius muscle strength, only in the experimental group $(p<0.05)$. In the comparison of theamount of change between exercise groups, the group that received feedback on CVA, CRA and tenderness threshold showed a significant change than the group without feedback $(\mathrm{p}<0.05)$.

Conclusions: As a result of this study, it can be seen that the therapist's real-time feedback is more effective in improving the forward head posture. This requires feedback from the therapist on posture correction during non-face-to-face exercise intervention.

Key Words: Non face to face, Exercise, Feedback, Forward head posture

서론

신종 코로나바이러스 감염증(코로나19)으로 인한 재택 근무, 비대면 원격 수업 등으로 집에 머무는 시간이 늘어 나면서 전자기기 사용도 자연스럽게 증가하고 있다[1]. 하 지만 전자기기 사용 시 잘못된 자세를 유지하게 되면 여 러 근골격계 질환에 노출될 수 있다[2]. 가장 대표적인 근 골격계 질환은 앞쪽머리자세인 거북목증후군이다[3]. 앞쪽 머리자세는 머리가 척추를 기준으로 하여 신체의 중력선 앞으로 이동되어 있는 상태로[4] 목의 과도한 폄을 유발
한다. 또한 목과 어깨 부위 특정 근육의 과사용을 유발하 며[5] 이러한 과사용은 근 긴장도 이상 등의 손상을 입히 고, 목의 뒤쪽과 어깨에 부하를 증가시켜 스트레스를 유 발한다[6]. 많은 선행연구에서 전방머리자세가 장시간 지 속되면 큰가슴근, 위등세모근, 어깨올림근이 단축되어 경 직되고, 앞톱니근, 마름근, 중간등세모근, 아래등세모근, 깊은 목 굽힘근이 약화되어[7] 심부 근육의 약화를 유발 한다고 하였다. 또한 지속적인 근 수축으로 근막 조직에 비정상을 유발하여 근육의 압통과 근막 통증을 발생시키 게 된다. 
앞쪽머리자세로 인한 문제점을 개선하기 위해 최근 물 리치료 분야에서는 테이핑, 근력강화운동, 신장운동 등 다양한 운동프로그램들이 많이 시도되고 있는데 그 중 근력강화운동과 신장운동이 가장 폭넓게 사용되고 있다 고 한다[8]. 선행연구에서는 앞쪽머리자세가 있는 성인을 대상으로 근력강화운동과 신장운동을 실시한 결과 앞쪽 머리각도가 감소하여 자세 정렬에 긍정적인 영향을 주었 음을 알 수 있다[9]. 이전 선행연구들의 운동프로그램 제 공 방식은 대부분 환자와 치료사가 직접 만나 수행되었 지만 현재 사회적 상황 상 대면하여 지도하는 것이 어려 워지게 되면서 비대면 운동프로그램에 대한 관심도가 증 가하였다.

특히 병원, 헬스장, 센터 등과 같은 장소에서 운동하 는 것이 제한되며 '홈-트레이닝'이 각광을 받고 있으며 운동 동영상, 운동 관련 어플에 대한 인기가 상승하고 있다. 집에서 운동을 쉽게 따라할 수 있도록 다양한 정 보를 제공하는 홈-트레이닝 동영상은 쉽게 접할 수 있지 만 단순한 과제를 대상자가 스스로 반복 수행 시 자세 에 대한 실시간(구두) 피드백이 주어지지 않아 동작에 대한 정확한 자세를 취하기가 쉽지 않다[10]. 이런 문제 점을 해결하기 위한 원격재활 시 적용되는 피드백에는 시각적 피드백, 구두 피드백, 동작 분석 피드백 등의 방 법들이 이용되는데, 이러한 문제점을 해결하기 위해 원 격재활 프로그램은 치료사의 지도하에 실시간 피드백을 제공함으로써 치료사와 환자 간에 상호작용이 가능하다 [11].

원격재활은 기기장치와 통신망을 이용하여 거리의 제 약 없이 치료사와 환자가 건강관리를 위하여 상호작용하 는 것으로 정의된다. 미국과 영국 등 많은 나라에서는 심 장호흡계 물리치료, 신경계질환 분야에서 다양한 원격재 활 운동프로그램을 1990년대부터 실시하였고, 현재까지 도 활발하게 진행되고 있다[12]. 현재 원격재활은 코로나 19 라는 상황으로 인해 수요와 발전에 가속이 붙은 상황 이다. 하지만 아직 국내에선 원격재활 운동프로그램을 적용한 연구가 부족하고. 또한 감염병의 확산으로 비대 면 운동에 대한 관심이 증가되었지만 대면 치료와 비슷 하고 기본이 되는 피드백 방법인 구두 피드백의 중요성 을 다루는 관점의 연구는 미비하다. 따라서 본 연구는 앞 쪽머리자세 환자를 위한 비대면 복합운동 프로그램을 기 반으로 원격재활을 활용하여 치료사의 실시간(구두) 피 드백의 유무에 따라 자세, 근력, 압통역치에 미치는 영향 을 알아보고 실험결과의 임상적 활용 가능성을 제시하고 자 한다.

\section{연구방법}

\section{연구대상자}

본 연구는 대전광역시에 위치한 $\mathrm{D}$ 대학교에 재학 중인 학생들을 대상으로 시행하였다. 대상자 선정 기준은 20 대 의 건강한 성인으로 $\mathrm{CVA}$ (Craniovertebral angle) $52^{\circ}$ 이 하인 자를 대상으로 하였다. 제외 기준은 1) CVA $52^{\circ}$ 이 상인 자[13], 2) 척추 질환자, 3) 주3회 이상의 규칙적인 운동을 수행하는 자, 4) 3 개월 이내의 목 및 상지에 정형 외과적 문제가 있는 자, 5) 2주간의 중재에 참여할 수 없 는 자로 정하였다.

대상자표본 수를 추출하기 위해 Cohen의 표본추출 공 식에 따른 표본 수 계산 프로그램인 $\mathrm{G}^{*}$ Power 3.1.9.2 프 로그램을 이용하였다. 선행연구에서 분석하고자 하는 그 룹 간 비교 검정을 위해, Means: Difference between two independent means (two groups)를 이용하였다. 선 행연구에서 기재된 변수의 값을 계산하여 효과 크기 1.5135135 가 추출되었다. 표본 수를 추출하기 위해, 효과 크기 1.5135135 , 유의수준 0.05 , 검정력 0.9 로 설정한 후 표본 크기를 산출한 결과, 각 군의 최소 표본 크기는 11 명으로 전체 대상자 수는 22명이 필요로 했다. 본 연구는 많은 탈락자를 우려하여 대상자를 총 71 명을 모집하였으 며, 제외 조건과 중간 탈락자를 제외하고 실험군 12 명, 대 조군 12 명이 배정되어 총 24 명의 대상자가 연구에 참여 하였다[14].

실험에 앞서 본 연구의 목적과 방법, 순서에 대한 설명 을 시행하였고 자발적 참여의사를 밝히고 서명한 대상자 들만 실험에 참여하였다. 본 연구는 대전대학교 연구 윤 리 위원회에 승인(1040647-202104-HR-009-03)을 받아 연구를 진행하였다.

\section{연구절차}

본 연구는 무작위 통제 실험으로 진행되었으며, 실험군 -대조군의 사전-사후검사 설계이다. 선정조건을 통해 30 명의 대상자가 최종 선정되었고, 두 군으로 무작위 배정 하였다. 본 연구는 블라인드 방식으로 수행되었으며, 실험 군과 대조군의 대상자들은 각각 자신이 어느 그룹에 속해 있는지 알지 못한 채로 운동프로그램을 시행하도록 실험 이 진행되었다 중재 전에 자세, 근력, 압통역치를 사전 평 가하였다. 두 군 모두 동일한 운동영상을 제공받았다. 실 험군은 운동영상과 함께 운동 수행 시 치료사의 실시간 피드백을 받으며 운동을 진행하였고, 대조군은 운동영상 만 보고 스스로 운동을 실시하였다. 운동프로그램은 30 분 이며 주 3 회씩 2 주간 시행하였다. 2 주 동안 각 군에서 운 동을 수행하지 못한 탈락자가 3명씩 발생하여 최종적으로 


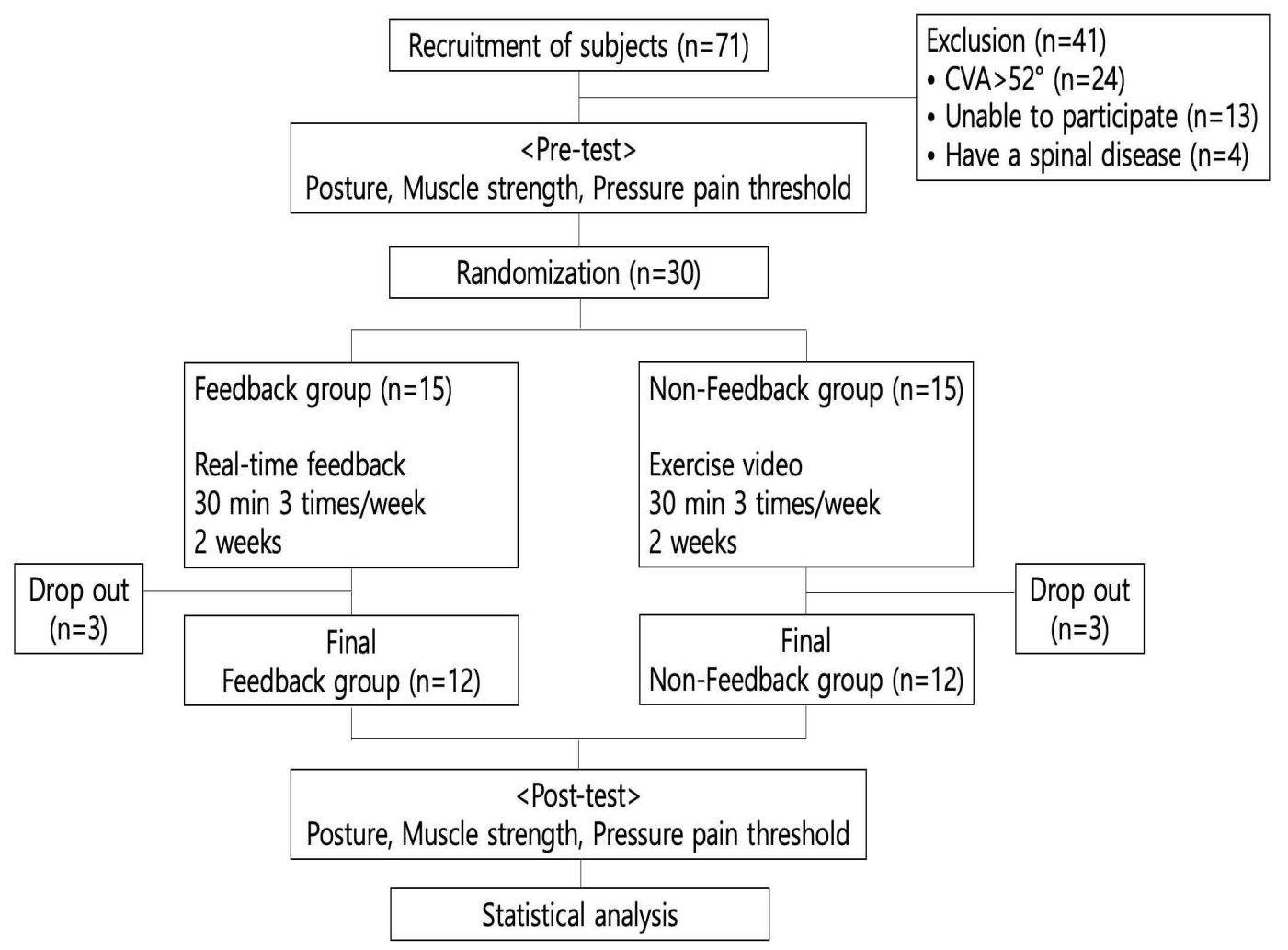

Figure 1. Flow chart

각 군당 12 명씩의 인원이 실험을 마쳤다. 중재가 끝난 후 에 사후평가를 실시하였다. 전체적인 연구 설계는 Figure 1 과 같다.

\section{중재방법}

본 연구의 운동 프로그램은 선행연구의 운동 프로그램 을 수정 및 보완하여 활용하였으며, 근력강화운동, 신장운 동을 합친 복합 운동으로 구성하였다 $[14,15]$. 앞쪽머리자 세로 인한 근육의 불균형으로 앞톱니근, 마름근, 중간 등 세모근, 아래 등세모근이 약화되고, 큰가슴근, 위등세모근, 어깨올림근이 단축되어 이에 대한 운동을 동영상으로 제 작하였다.

운동 프로그램은 주 3 회 1 일 30 분씩, 총 2 주간 실시하 였다. 각 운동마다 3 세트로 구성되어 있으며 한 세트가 끝난 후에 10 초의 휴식을 주면서 운동을 진행하였다. 2 주 차에는 1 주차와 같은 동작으로 구성되었으며, 저항을 부 가하여 운동의 난이도를 높여 실시하였다.

\section{실시간 피드백 비대면 중재프로그램(실함군)}

운동프로그램 제공 방식으로는 실험군에는 자체 제작 한 운동 영상과 함께 줌 비디오 커뮤니케이션(version
5.0, Zoom, USA) 프로그램을 이용하여 운동을 수행하는 대상자들에게 실시간으로 자세 교정을 위한 구두 피드백 을 주었다. 운동 수행 전 대상자들에게 운동 방법과 운동 과정(카메라 설치 등)에 대한 사전교육을 실시하였고, 대 상자들은 제공된 영상을 보면서 30 분간 운동을 수행하였 다. 대상자들에게는 각 운동마다 피드백이 주어졌다. 치료 사는 운동을 하고 있는 대상자에게 '배에 힘을 주세요', ‘팔을 더 들어 올리세요' 등과 같이 음성으로 자세를 교정 해 주었으며, 대상자에게 운동 중간에 '조금만 더 버티세 요', '잘하고 있어요' 라고 말해주며 동기부여와 격려를 제공하였다. 또한 각 운동을 수행할 때 어떤 느낌을 가져 야 하는지 설명하면서 보상작용이 발생하지 않게 올바른 자세를 취하도록 도와주었다. 운동을 마친 후에는 어려운 점이나 힘든 점을 물어보며 각 대상자에 맞게 난이도를 조정하였다(Figure 2).

\section{피드백 없는 비대면 중재 프로그램(대조군)}

대조군은 실험군과 동일한 운동 영상을 제공하여 자발 적인 운동을 수행하도록 하였다. 실험군과 마찬가지로 운 동 시행 전에 대상자들에게 운동 방법에 대한 사전교육을 실시하였다. 운동 영상에는 운동 시 주의사항이 포함되어 있으며, 대상자는 운동영상에 있는 주의사항만을 통해 스 

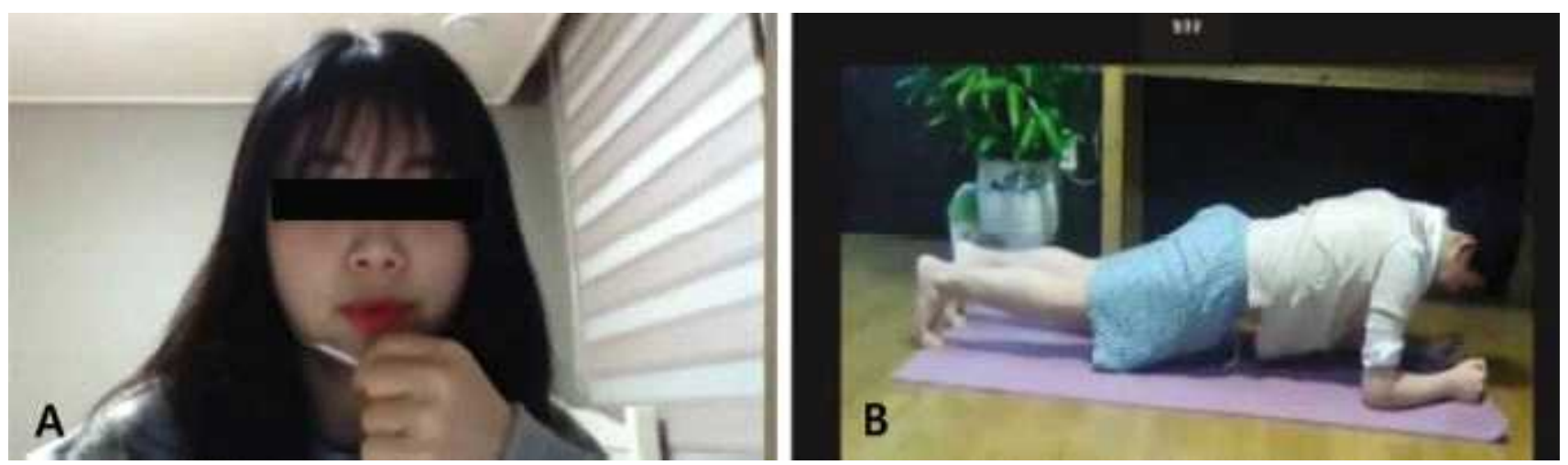

Figure 2. 비대면 중재프로그램 $<\mathrm{ZOOM}>\mathrm{A}$ : 치료사의 피드백 화면 B: 비대면 운동화면

스로 자세를 교정하며 운동을 시행하였다. 운동의 수행 여부를 확인하기 위하여 치료사가 전화나 문자로 운동 참 여를 독려하였고, 운동시행 여부는 동영상에 댓글을 다는 걸로 확인하였다.

\section{평가방법}

\section{자세 평가}

대상자는 고정된 의자에 앉아 시선은 정면을 보고 편안 하게 자세를 취하며 팔을 자신의 무릎 위에 올리도록 하 였다. 대상자로부터 $80 \mathrm{~cm}$ 떨어진 거리에 삼각대를 위치 시킨 후 디지털 카메라를 대상자의 어깨에 맞춰 높이를 조절하여 촬영하였다. 대상자는 자연스러운 머리 자세 (neutral head posture; NHP)가 되도록 목을 최대한 앞으 로 굽혔다가 뒤로 젖히는 동작을 3 회 정도 반복하여 실시 하였다[16]. 측정자는 도수 촉진으로 대상자의 제7번 목 뼈(C7)의 가시돌기와 귀 구슬에 스티커로 표시를 한 후 측면 모습을 디지털 카메라로 촬영하였다. 본 연구는 ImageJ 소프트웨어(1.52version, National Institutes of Health, USA)를 이용하여 각도를 측정하였다.

$\mathrm{CVA}$ (Craniovertebral angle)는 C7의 가시돌기를 지 나는 수평선과 귀 구슬을 연결한 선이 이룬 각이며, $\mathrm{CRA}$ (CranioRotation angle)는 C7의 가시돌기와 귀 구슬 을 연결한 선과 귀의 이주와 눈의 가쪽안각을 연결한 선 에 의해 형성된 각으로 정의하였다[17]. 본 연구에서는 머 리목각도가 $52^{\circ}$ 이하인 경우로 설정하였으며[13], 측정자 내 신뢰도는 $\mathrm{r}=0.88$ 이다[18].

\section{근력 평가}

근력은 Digital Handheld Dynamometer muscle tester (MicroFET2 Manual Muscle Tester, Hoggan, USA)를 이용하여 등척성 근력을 측정하였으며 기구의 신뢰도는 $\mathrm{ICC}=0.95$ 이다[19]. 중간 등세모근의 근력측정 자세는 엎
드린 자세에서 팔꿉관절 $90^{\circ}$ 굽힘, 어깨 $90^{\circ}$ 벌린 상태로 어깨뼈를 모아 뒤당김 자세를 취하게 하였다. 측정위치는 어깨뼈 가시의 중간부분으로 하였고, 저항은 $90^{\circ}$ 벌림으 로 어깨뼈 장축에 평행한 측면방향으로 가해졌다[20]. 아 래 등세모근은 엎드린 자세로 어깨 $140^{\circ}$ 벌림하여 어깨뼈 모음 자세를 취하게 하였다. 측정위치는 어깨뼈 가시의 중간부분으로 어깨뼈에 가해지는 저항은 위팔뼈의 장축에 평행한 위쪽과 측면 쪽으로 가해졌다[20]. 근력은 중재 전 후 각 2회씩 측정하였고 평균값을 사용하였다.

\section{압통 역치 평가}

근육의 압통역치는 Wagner FORCE TENTM(FDX-25, Wagner Instrument Greenwhich CT, USA)를 이용하여 측정하였다. 측정위치는 대상자의 양쪽 위 등세모근을 촉 진하여 양쪽 등세모근의 중간위치를 표시하여, 그 부분에 압력을 가하였다. 압력은 $5 \mathrm{~N} / \mathrm{S}$ 의 속도로 가해졌다. 압력 통증 역치는 편안한 압력에서 통증으로 변하는 시점으로 정의하였으며, 측정 전 대상자에게 압력을 가했을 때 조 금이라도 통증이 느껴진다면 대상자가 '아' 소리를 내고, 검사자는 즉시 측정 기구를 제거하였다[21]. 측정자 간 신 뢰도는 ICC: 0.79-0.90로 나타났다[22]. 압통은 중재 전 후 각 2 회씩 측정하였고 평균값을 사용하였다. 측정간의 간격은 10 초로 동일하게 시행했다.

\section{통계분석}

본 연구에서 얻은 자료는 IBM SPSS(SPSS ver. 25.0, IBM Co., USA)을 이용하여 분석하였다. 측정된 변수들 의 정규성 검정을 위하여 샤피로-윌크(Shapiro-Wilk) 검 정 시행했다. 실험군과 대조군의 집단 내 운동 전·후 값 을 비교하기 위해 대응표본 $\mathrm{t}$ 검정을 사용하였고, 두 집단 간 유의성을 검정하기 위해 독립표본 $\mathrm{t}$ 검정을 사용하였 다. 그룹 간 중재 효과의 크기는 Cohen's d값을 사용하여 
추출하였다. 모든 통계적 유의수준은 $\alpha=0.05$ 로 하였다.

\section{연구결과}

본 연구에 참여한 대상자는 총 30 명이였으며, 이 중 실 험과정에서 탈락자 6 명이 발생하여 24명의 인원을 대상으 로 시행하였다. 총 24명 중 실시간 피드백군(실험군) 12 명, 비 실시간 피드백군(대조군) 12 명으로 구성하였으며 대상자의 일반적인 특성은 Table 1 과 같다. 두 군간 일반 적 특성은 통계적으로 유의한 차이가 없이 동질하였다 $(\mathrm{p}>0.05)$.

중재 전 $\mathrm{CVA}$ 와 $\mathrm{CRA}$ 값은 두 군 간의 유의한 차이가 없이 동질 하였다. 각 군의 $\mathrm{CVA}$ 은 전-후 비교에서는 실 험군과 대조군 모두 중재 후 유의하게 증가하였다 $(\mathrm{p}$ $<0.05)$. 두 군간 $\mathrm{CVA}$ 변화량 비교에서는 실험군이 대조 군에 비해 더 유의하게 큰 증가를 보였다 $(\mathrm{p}<0.05)$. 각 군 의 CRA 전-후 비교에서는 실험군에서만 중재 후 유의한 증가를 보였다 $(\mathrm{p}<0.05)$. 대조군에서는 전-후에 유의미한 차이가 나타나지 않았다 $(\mathrm{p}>0.05)$. 두 군간 $\mathrm{CRA}$ 변화량 비교에서는 실험군과 대조군에 유의한 차이를 보이지 않
았다 $(\mathrm{p}<0.05)($ Table 2$)$.

중재 전 중간-아래 등세모근 값은 두 군 간의 유의한 차이가 없이 동질 하였다. 각 군의 근력 전-후 비교에서는 왼쪽 중간등세모근의 실험군에서 만 유의한 증가를 보였 고 $(\mathrm{p}<0.05)$, 오른쪽 중간등세모근, 아래 등세모근의 전후 비교에서는 실험군, 대조군 모두 유의미한 차이가 나 타나지 않았다 $(\mathrm{p}>0.05)$. 두 군간 중간-아래 등세모근의 변화량 비교에서는 실험군과 대조군에 유의한 차이를 보 이지 않았다 $(\mathrm{p}>0.05)($ Table 3$)$.

중재 전 등세모근의 압통 역치 값은 두 군 간의 유의한 차이가 없이 동질 하였다. 각 군의 압통 역치 값에 대한 전-후 비교에서는 실험군과 대조군 모두 중재 후 유의하 게 증가하였다 $(\mathrm{p}<0.05)$. 두 군간 압통 역치 변화량 비교 에서는 실험군이 대조군에 비해 더 유의하게 큰 증가를 보였다 $(\mathrm{p}<0.05)($ Table 4$)$.

\section{고찰}

본 연구는 앞쪽머리자세에 대한 비대면 운동 중재 시 치료사의 피드백이 자세, 근력, 압통역치에 미치는 효과를

Table 1. The General characteristics of subjects

$(n=24)$

\begin{tabular}{llll}
\hline & Feedback group $(\mathbf{n}=\mathbf{1 2})$ & Non-Feedback group $(\mathbf{n}=\mathbf{1 2})$ & $\mathbf{x}^{\mathbf{2}} / \mathbf{t}$ \\
\hline Sex $(\mathrm{M} / \mathrm{F})$ & $8 / 4$ & $8 / 4$ & 0.000 \\
Age $($ year $)$ & $22.83(1.11)$ & $22.92(1.38)$ & -0.163 \\
Height $(\mathrm{cm})$ & $164.75(7.39)$ & $162.83(9.71)$ & 0.544 \\
Weight $(\mathrm{kg})$ & $61.17(11.82)$ & $58.25(11.25)$ & 0.619 \\
\hline
\end{tabular}

The values are presented mean (SD)

${ }^{*} \mathrm{p}<0.05$

Table 2. Comparison of CVA, CRA between Feedback Group and Non- Feedback Group in forward head

$(n=24)$

\begin{tabular}{|c|c|c|c|c|c|}
\hline & & Feedback group $(n=12)$ & Non Feedback group $(n=12)$ & $\mathbf{t}$ & Effect size \\
\hline \multirow[t]{4}{*}{$\operatorname{CVA}\left({ }^{\circ}\right)$} & Pre & $46.93(3.92)$ & $48.63(2.84)$ & -1.213 & \multirow{4}{*}{0.96} \\
\hline & Post & $53.08(3.66)$ & $51.34(4.59)$ & 1.030 & \\
\hline & $t(p)$ & $-7.047^{*}$ & $-2.340^{*}$ & & \\
\hline & Change & $6.15(3.02)$ & $2.71(4.02)$ & $2.368^{*}$ & \\
\hline \multirow[t]{4}{*}{$\mathrm{CRA}\left({ }^{\circ}\right)$} & Pre & $153.98(8.87)$ & $149.09(6.04)$ & 1.581 & \multirow{4}{*}{0.89} \\
\hline & Post & $147.39(6.87)$ & $147.71(5.82)$ & -0.121 & \\
\hline & $\mathrm{t}(\mathrm{p})$ & $3.606^{*}$ & 0.915 & & \\
\hline & Change & $-6.59(6.34)$ & $-1.38(5.23)$ & $-2.198 *$ & \\
\hline
\end{tabular}

The values are presented mean (SD)

${ }^{*} \mathrm{p}<0.05$ 
Table 3. Comparison of Trapezius muscle strength between Feedback Group and Non-Feedback Group

\begin{tabular}{|c|c|c|c|c|c|c|}
\hline & & & Feedback group $(n=12)$ & Non Feedback group $(n=12)$ & $\mathbf{t}$ & Effect size \\
\hline \multirow[t]{4}{*}{ LT-Middle } & Trapezius & Pre & $7.98(3.50)$ & $7.31(2.92)$ & 0.503 & \multirow{4}{*}{0.15} \\
\hline & & Post & $9.41(4.78)$ & $8.41(3.31)$ & 0.596 & \\
\hline & & $\mathrm{t}(\mathrm{p})$ & $-2.366^{*}$ & -1.654 & & \\
\hline & & Change & $1.44(2.10)$ & $1.10(2.30)$ & 0.375 & \\
\hline \multirow[t]{4}{*}{ RT-Middle } & Trapezius & Pre & $7.99(3.71)$ & $7.15(2.98)$ & 0.613 & \multirow{4}{*}{0.24} \\
\hline & & Post & 8.09 (4.93) & $8.00(2.98)$ & 0.050 & \\
\hline & & $t(p)$ & -0.087 & -1.653 & & \\
\hline & & Change & $0.10(3.98)$ & $0.86(1.80)$ & -0.601 & \\
\hline \multirow[t]{4}{*}{ LT-Lower } & Trapezius & Pre & $7.54(4.17)$ & $6.75(2.28)$ & 0.577 & \multirow{4}{*}{0.04} \\
\hline & & Post & $8.50(4.44)$ & $7.82(2.21)$ & 0.480 & \\
\hline & & $\mathrm{t}(\mathrm{p})$ & -1.508 & -1.626 & & \\
\hline & & Change & $0.96(2.21)$ & $1.07(2.27)$ & -0.114 & \\
\hline \multirow[t]{4}{*}{ RT-Lower } & Trapezius & Pre & $6.93(3.30)$ & $6.90(2.86)$ & 0.026 & \multirow{4}{*}{0.36} \\
\hline & & Post & $8.33(4.57)$ & 7.33 (2.09) & 0.687 & \\
\hline & & $\mathrm{t}(\mathrm{p})$ & -2.021 & -0.525 & & \\
\hline & & Change & $1.40(2.39)$ & $0.43(2.86)$ & 0.894 & \\
\hline
\end{tabular}

The values are presented mean (SD)

${ }^{*} \mathrm{p}<0.05$

Table 4. Comparison of Pressure Pain Threshold(PPT) between Feedback Group and Non-Feedback Group in Upper

Trapezius

$(n=24)$

\begin{tabular}{|c|c|c|c|c|c|c|}
\hline & & & Feedback group $(n=12)$ & Non Feedback group $(n=12)$ & $\mathbf{t}$ & Effect size \\
\hline \multirow[t]{4}{*}{ Lt-Upper } & Trapezius & Pre & $25.55(8.61)$ & $21.83(5.08)$ & 1.290 & \multirow{4}{*}{0.88} \\
\hline & & Post & $35.47(10.38)$ & $26.53(6.09)$ & $2.574^{*}$ & \\
\hline & & $t(p)$ & $-4.973^{*}$ & $-3.500^{*}$ & & \\
\hline & & Change & $9.91(6.90)$ & $4.69(4.64)$ & $2.173^{*}$ & \\
\hline \multirow[t]{4}{*}{ Rt-Upper } & Trapezius & Pre & $22.90(6.50)$ & $22.87(6.94)$ & 0.110 & \multirow{4}{*}{1.06} \\
\hline & & Post & $35.48(10.11)$ & $29.02(9.94)$ & 1.580 & \\
\hline & & $t(p)$ & $-6.430^{*}$ & $-4.082^{*}$ & & \\
\hline & & Change & $12.59(6.78)$ & $6.15(5.22)$ & $2.606^{*}$ & \\
\hline
\end{tabular}

The values are presented mean (SD)

${ }^{*} \mathrm{p}<0.05$

알아보고자 하였다. 이에 피드백을 적용한 실험군과 피드 백 없이 운동만을 진행한 대조군에 근력강화운동과 신장 운동을 합친 복합운동 중재를 2주간 적용하였고 자세, 근 력, 압통역치를 중재 전후로 측정하여 변화를 알아보았다.

$\mathrm{CVA}$ 는 중재 전 후 평가에서 실험군과 대조군 모두 유 의한 향상이 일어났다. 이 결과는 중간-아래 등세모근과
앞톱니근, 마름근의 근력강화운동과 큰가슴근과 위 등세 모근의 신장운동을 수행한 이송희[14]의 연구와 동일한 결과를 보여준다. 이는 본 연구에서 적용한 2주간의 복합 운동이 앞쪽머리자세에서 발생하는 뒤통수밑근 등의 단축 된 근육에는 스트레칭을, 깊은목굽힘근, 마름근등 약화된 근육[7]에는 수축 운동으로 자극 해줌으로써 재활성화 시 
켜 올바른 자세로의 개선 효과가 나타난 것으로 보인다. $\mathrm{CRA}$ 에 대한 중재 전 후 평가에서 실험군은 유의한 감소 가 나타났지만 대조군에서는 유의한 감소가 나타나지 않 았다. 본 연구와는 대조적으로 앞쪽머리자세에 대한 근력 강화운동과 스트레칭을 적용한 최영준[23]의 연구결과는 $\mathrm{CRA}$ 의 유의미한 감소가 나타났는데, 이는 근력강화운동 시 발생한 보상작용에 대한 억제와 피드백 적용의 효과[9] 로 사료된다. CVA와 CRA에 대한 두 집단의 변화량 비 교에서는 실험군에 통계적으로 유의미한 차이가 나타났는 데, 이는 자세 피드백이 앞쪽머리자세 환자의 통증치료에 미치는 영향을 연구한 임증완[24]의 연구와 마찬가지로 신장운동 수행 시 발생할 수 있는 보상작용에 대한 지도 사의 통제와 실시간으로 주어지는 올바른 피드백이 목표 로 하는 근육의 신장에 효과적이었다고 사료된다.

본 연구의 근력 평가를 위한 왼쪽, 오른쪽 중간, 아래 등세모근 중재 전 후 평가에서는 왼쪽 중간등세모근의 실 험군에서 만 유의미한 향상이 나타났고, 나머지 중간, 아 래 등세모근의 중재 전-후 평가에서는 유의미한 향상이 나타나지 않았다. 이는 8 주간의 근력강화운동과 스트레칭 중간, 아래 등세모근의 유의미한 근력 향상이 일어난 Lynch[8]와 대조되는 결과이다. 하지만 Lynch[8]의 연구 에서는 중재 기간이 8 주였고, 대상자가 엘리트 수영선수 였다는 부분에서 본 논문의 효과와 차이가 발생했다고 사 료된다. 또한 중간, 아래등세모근에 대한 두 집단의 변화 량 비교에서 실험군에 통계적으로 유의한 차이가 나타나 지 않았는데, 이는 실험군에 대한 실시간 자세 피드백이 비대면으로 진행되기 때문에 근력강화운동 중 나타날 수 있는 자세의 변화에 대한 피드백으로는 목표로 하는 근육 의 활성화 정도를 알 수 없다는 비대면 피드백의 한계라 고 생각된다.

본 연구에서는 왼쪽 위 등세모근의 압통 역치 평가는 중재 전 후 평가에서 실험군과 대조군 모두 유의미한 향 상이 일어났다. 이는 전방머리자세 개선을 위한 깊은목굽 힘운동, 어깨뼈안정화운동, 가슴이완운동을 하였고 위등세 모근의 압통역치가 유의하게 증가한 김용진[25]의 연구와 일치한다. 스트레칭으로 인해 근방추와 골지힘줄기관이 자극되어 근육의 긴장이 완화되고, 신장성이 증가되므로 [26], 본 연구의 신장운동이 위 등세모근의 긴장 완화와 혈액 순환을 증가시켜 근경직도를 감소시켰다고 사료된 다. 또한 위 등세모근의 압통역치에 대한 실험군, 대조군 두 집단의 변화량 비교에서 실험군에 대한 통계적으로 유 의한 차이가 나타났다. 이는 본 연구의 위등세모근 스트 레칭이 다각도의 관찰이 필요하지 않는 스트레칭으로 구 성되어있어, 실험군에 대한 위등세모근 신장운동 시 나타 나는 보상작용 통제와 신장 정도에 대한 피드백이 효과적 이었다고 생각된다.
위와 같은 결과를 통해서 실시간 피드백 제공은 올바른 동작을 수행하게 하고 운동 효과에 긍정적인 영향을 줄 것이라고 생각된다. 따라서 피드백의 효과가 입증된 본 연구결과를 바탕으로 환자의 운동효과를 향상시키기 위해 다양한 분야에서 물리치료사 역할이 더욱 커질 것이라 생 각된다.

본 연구에는 몇 가지 제한점이 있다. 첫째, 연구에 참여 한 20 대 대학생들을 대상으로 연령이 한정되어 연구결과 를 일반화하는 데 있어 어려움이 있다. 둘째, 중재 기간을 2 주라는 짧은 기간 동안 진행하였기 때문에 장기적인 효 과 비교에 한계가 발생한다. 셋째 비대면 자세 피드백 시, 대상자의 운동중재 시 카메라각도가 고정되어 있기 때문 에 다양한 각도에서의 확인이 부족하여 피드백에 대한 확 실한 효과에 대해 일반화하는데 어려움이 있다. 따라서 향후 연구에서는 다양한 연령층과 비대면 피드백 방법의 개선과 더불어 장기적인 연구가 필요하다고 생각된다.

본 연구는 전방머리자세에 대한 비대면 복합 운동프로 그램 시 치료사의 피드백에 따른 자세교정이 자세, 근력, 압통역치에 미치는 영향을 알아보고자 CVA, CRA, 중간 등세모근 근력, 아래등세모근 근력, 위 등세모근 압통역치 의 변화량을 비교하였다. 연구결과, 치료사의 실시간 피드 백을 제공받아 운동을 수행한 실험군과 동영상만을 시청 하여 운 측정 자료를 분석한 결과, 실험군과 대조군 모두 머리척추각도, 압통역치에서는 유의한 개선의 효과를 보 였다. 반면에 머리회전각도, 왼쪽 중간 등세모근 근력에서 는 피드백을 제공받은 실험군에서 만 유의한 개선의 효과 를 보였다. 두 집단의 변화량을 비교한 결과 머리척추각 도, 머리회전각도, 위등세모근의 압통역치에서 유의한 차 이를 보였다. 반면 중간 등세모근, 아래 등세모근의 근력 에는 유의한 차이를 보이지 않았다. 이러한 결과는 전방 머리자세 환자에게 비대면 복합 운동프로그램 수행 시 치 료사의 피드백이 잘못된 자세를 교정시켜 운동 효과 향상 에 더욱 효과적이라는 것을 알 수 있다. 따라서 코로나19 로 인해 대면으로 지도하기 어려운 상황에서 비대면 운동 중재 시 치료사의 피드백이 필요하다고 생각된다.

\section{참고문헌}

1. Bae YI, Shin HR. Corona 19 Accelerates Untact Society. Issues \& Diagnosis. 2020;416:1-26.

2. Eom SH, Choi SY, Park DH. An empirical study on relationship between symptoms of musculoskeletal disorders and amount of smartphone usage. J Korea Saf Manage. 2013;15:113-120.

3. Kim Y, Khil J. Effects of Exercise Training and Chiropractic on Grip Strength and Cervical Muscle 
Strength of Subjects with Forward Head Posture and Turtle Neck. J Korean Soc Phys Med. 2017;12:121-7.

4. Harman K, Hubley-Kozey CL, Butler H. Effectiveness of an Exercise Program to Improve Forward Head Posture in Normal Adults: A Randomized, Controlled 10-Week Trial. J Manual ManipTher. 2005;13:163-76.

5. Lee SG, Lee YS, Chung YJ. Effect of changes in head postures during use of laptops on muscle activity of the neck and trunk. Phys Ther Rehabil Sci. 2017;6:33-8.

6. Lau KT, Cheung KY, Chan KB, Chan MH, Lo KY, Chiu Thomas tai wing. Relationships between sagittal postures of thoracic and cervical spine, presence of neck pain, neck pain severity and disability. Man Ther. 2010;15:457-62.

7. Lee DH. The effects of balance exercise and stretching exercise on forward head posture. Daegu: Daegu University; 2011.

8. Lynch SS, Thigpen CA, Mihalik JP, Prentice WE, Padua Darin. The effects of an exercise intervention on forward head and rounded shoulder postures in elite swimmers. Br J Sports Med. 2010;44:376-81.

9. Park HK, Yang BI. Effects of Quadruped Exercise and Wall Slide Exercise on Shoulder Height and Muscle Activity of University Students with Rounded Shoulders. J KANPT. 2020;24:39-45.

10. Chon SC, Chang KY. The Effects of virtual reality therapy with compensation inhibition and feedback on upper extremity function in hemiplegic patients with chronic stroke. J Korean Acad University Trained Phys TH. 2011;18:67-75.

11. McCue M, Thompson J. HealthSouth's Inpatient Rehabilitation Facilities: How Does Their Performance Compare With Other For-Profit and Nonprofit Inpatient Rehabilitation Facilities? Arch Phys Med Rehabil. 2010;91:708-13.

12. Eriksson L, Lindström B, Gard G, Lysholm J. Physiotherapy at a distance: a controlled study of rehabilitation at home after a shoulder joint operation. J Telemed Telecare. 2009;15:215-20.

13. Kang HJ, Yang HS. The Effects of the Action Observation and Visual Feedback Convergence Exercise on the Alignment, Pain and Function of Forward Head Posture and Round Shoulder Posture. J Korea Converg Soc. 2018;9:123-8.

14. Lee SH, Lee JH. Effects of strengthening and stretching exercises on the forward head posture. J Int Acad Phys Ther Res. 2016;7:1046-50.

15. Lee JD, Shin WS. Immediate effect of neuromuscular control exercise on neck pain, range of motion, and proprioception in person with neck pain. Phys Ther Rehabil Sci. 2020;9:1-9.

16. Lee JN, Jung SM, JeonJH. The Effect of Rectus Abdominis Functional Massage on Forward head posture and Pain in Patients with Chronic Neck Pain. J Korean Acad Orthop Man PhysiTher. 2018;24:15-21.

17. Chae YW. The measurement of forward head posture and pressure pain threshold in neck muscle. J Korean Soc Phys Ther. 2002;14:117-24.

18. Nemmers TM, Miller JW, Hartman MD. Variability of the Forward Head Posture in Healthy Community-dwelling Older Women. J Geriatr Phys Ter. 2009;32:10-4.

19. Buckinx F, Croisier JL, Reginster JY, Dardenne N, Beaudart C, Slomian J, et al. Reliability of muscle strength measures obtained with a hand-held dynamometer in an elderly population. Clin PhysiolFunct Imaging. 2015;37:332-40.

20. Michener LA, Boardman ND, Pidcoe PE, Frith AM. Scapular Muscle Tests in Subjects With Shoulder Pain and Functional Loss: Reliability and Construct Validity. Phys Ther. 2005;85:1128-38.

21. Hanney WJ, Puentedura EJ, Kolber MJ, Liu X, Pabian PS, Cheatham SW. The immediate effects of manual stretching and cervicothoracic junction manipulation on cervical range of motion and upper trapezius pressure pain thresholds. J Back Musculoskelet Rehabil. 2017;30:1005-13.

22. Walton D, MacDermid J, Nielson W, Teasell R, Chiasson M, Brown L. Reliability, Standard Error, and Minimum Detectable Change of Clinical Pressure Pain Threshold Testing in People With and Without Acute Neck Pain. J Orthop Sports Phys Ther. 2011;41:644-50.

23. Choi YJ, Hwang R. Effect of Cervical and Thoracic Stretching and Strengthening Exercise Programon Forward Head Posture. J Korea Content Assoc. 2011;11:293-300.

24. Lim JW. The effect of postural feedback on posture and the pain control of patients with forward head posture. Gyeongsan: Daegu Catholic University; 2017.

25. Kim YJ, Lee Sb, Jeon BS, Jeong SG, Kim BW. The Effects of Shoulder Stabilization and Thoracic 
Extensor Exercises Combined with Deep Neck

Flexor Exercise on Posture and Pressure Pain Threshold of Physical Therapist and Occupational Therapist with Turtle Neck Syndrome. JkoreanAcad Orthop Man PhysiTher. 2017;23:43-51.

26. Ko MG, Jeun YJ. The Effect of Stretching to Muscle Stiffness in Hospital Office Employees. Journal of the Korea Society of Computer and Information. 2020;25:125-30. 